Article

\title{
Incidents and Disaster Avoidance: The Role of Communication Management and the Organizational Communication Climate in High-Risk Environments
}

\author{
Shahrina Md Nordin 1,*, Ammar Redza Ahmad Rizal ${ }^{2}$, Rafidah Abd Rashid ${ }^{1}$, Rohayu Che Omar ${ }^{3}$ \\ and Unggul Priyadi 4 \\ 1 Centre of Social Innovation, Universiti Teknologi PETRONAS, Bandar Seri Iskandar 32610, Malaysia; \\ rafidah_20002048@utp.edu.my \\ 2 Faculty of Language and Communication, Universiti Malaysia Sarawak, Kota Samarahan 94300, Malaysia; \\ araredza@unimas.my \\ 3 Department of Civil Engineering, Universiti Tenaga Nasional, Kajang 43000, Malaysia; \\ rohayu@uniten.edu.my \\ 4 Faculty of Economics, Universitas Islam Indonesia, Yogyakarta 55584, Indonesia; unggul.priyadi@uii.ac.id \\ * Correspondence: shahrina_mnordin@utp.edu.my
}

check for

updates

Citation: Nordin, S.M.; Rizal, A.R.A.; Rashid, R.A.; Che Omar, R.; Priyadi,

U. Incidents and Disaster Avoidance:

The Role of Communication

Management and the Organizational Communication Climate in High-Risk Environments. Sustainability 2021, 13, 10138. https://doi.org/10.3390/ su131810138

Academic Editor: Judith Petts

Received: 8 July 2021

Accepted: 23 August 2021

Published: 10 September 2021

Publisher's Note: MDPI stays neutral with regard to jurisdictional claims in published maps and institutional affiliations.

Copyright: (c) 2021 by the authors. Licensee MDPI, Basel, Switzerland. This article is an open access article distributed under the terms and conditions of the Creative Commons Attribution (CC BY) license (https:// creativecommons.org/licenses/by/ $4.0 /)$.
Abstract: Health, safety and the working environment are of paramount importance, especially in the high-risk environments found at facilities in the oil and gas industry, where hazards are inevitable and accidents may lead to regrettable situations such as explosions, oil spills and other disasters. The high number of accidents and disasters at such facilities bring safety-related matters to the fore. The complexity of the communication process is very often underestimated, where failures in communication could lead to major disasters. This paper investigates the role of communication management and the organizational communication climate and their impact on incidents and disaster avoidance. This study embarks on a quantitative approach involving 260 personnel from high-risk workplaces at oil and gas facilities, based on purposive sampling. Hypotheses were tested using PLS-SEM to identify causal relationships and for mediation analysis. The findings of this study show that communication management and the organizational communication climate have a significant impact on disaster avoidance. The organizational communication climate is also found to be a significant mediator for the relationship between communication management and disaster avoidance. Communication management and the organizational communication climate need to be enhanced and to be integrated with other technology and innovation to improve safety regulation adherence in the oil and gas industry.

Keywords: safety communication; organizational communication climate; high-risk environment; disaster avoidance; leader-member exchange; safety commitment; oil and gas; workplace accident; hazardous

\section{Introduction}

The oil and gas industry is one of Malaysia's primary commodities; their contribution to the Malaysian economy comprises about 20 percent of Malaysia's GDP [1]. Malaysia offers the fourth-highest oil reserve and the third-highest natural gas reserve in the AsiaPacific region. It is not an understatement that the workers in the oil and gas sector are the "unsung heroes" of the Malaysian nation. This workforce, however, faces risks daily due to their highly hazardous work environment, in which the likelihood of incidents and injuries is high [2]. The employees face the risks of fire and explosions that could be caused by the ignition of flammable gases at the plants.

The fatality rate due to workplace accidents among oil and gas employees is seven (7) times higher compared to those in other industries. Hence, it is vital that companies in this sector ensure a safe working environment to minimize the risks of operational hazards. 
Past studies over the last few decades indicate an increase in incidents at workplaces around the world [2,3] including the oil and gas work environment [4]. Incidents at oil and gas plants could have numerous probable causes, especially during emergency management, start-ups, or shutdowns. The most common indicator of safety levels in a workplace is the number of injuries and fatalities; hence, companies strive for "zero lost-time injury" (LTI) [5]. It is however cautioned that zero lost-time injury (LTI) may be misleading, as it often encourages the assumption that major hazards at the plants are well managed, without further due diligence being performed. Complacency could eventually lead to an oversight regarding occupational hazards [6].

For this reason, continuous enhancement programs to ensure safety in the workplace environment are imperative, which highlights the importance and role of effective communications to avoid oil and gas incidents. For instance, effective communication during a shift handover could prevent major incidents $[7,8]$. The findings reported in this study specifically focus on communications management and disaster avoidance in oil and gas processing plants in Malaysia.

In Malaysia, the Occupational Safety and Health Act (OSHA) was passed on 25th February 1994. The enactment of the OSHA has significantly improved the health and safety environment in Malaysia [9]. Organizations in the oil and gas industry must comply with OSHA legislation to avoid accidents or near-misses [10]. Other safety indicators are derived from, for example, the American Petroleum Institute (API) and the International Association of Oil and Gas Producers (IOGP).

The operational condition safety (OTS) model, derived from quantitative risk assessment (QRA), lists communication as one of the performance standards [11]. Despite the OSHA and International Labor Organizations (ILO) which outline comprehensive guidelines, there is an increasing concern about safety performance. Some of the contributing causes to incidents include lack of safety communication [7-9,12], safety leadership [13], commitment to safety and unsafe behavior [9].

Effective communications management is one of the critical factors for ensuring safety in operations at oil and gas plants [7-9,12]. Poor communications regarding the operations at the plant, for example during the shift handover, could have a devastating impact. Past major incidents like Buncefield, Texas City and the Gulf of Mexico occurred largely due to poorly conducted shift handovers and a lack of communication of information [7]. Communication barriers create a challenge for promoting safety in an organization [14], as ensuring clarity, credibility and impact [15] are vital in safety communications.

Barriers to effective communication include a lack of information or knowledge, a lack of attention to detail, selective listening, status prejudice and differing perceptions of risks [16]. The lack of structure and insufficient information are often not well-documented in the shift logbooks, as it was found that $80 \%$ of the logbooks in the oil and gas industry's plants are unstructured and sometimes include unnecessary information with unclear key messages [8].

There is a plethora of research providing empirical evidence that effective communication management could improve work-related safety performance, which translates to disaster avoidance (e.g., $[7,17])$. However, the study reported in this paper focuses on the Malaysian context of the oil and gas industry. The study was conducted to investigate how an organizational communication climate and good communication management influence commitment to safety for avoiding incidents and disasters in a high-risk workplace environment. Previous studies related to safety communication in the oil and gas industry have focused on describing the current phenomena and investigating the relationship between communication and commitment [18].

There is also a study looking into the role of leader-workers that constitutes a safetybased organizational climate, and its impact on safety commitment [19]. In most of the existing studies, both communication and organizational climate are considered to be important antecedents that led to safety commitment. However, there is a limited study that further investigates the advanced role of or relationship between these two constructs. 
Henceforth, this study embarks on investigating whether an organizational communication climate is a mediator when explaining the relationship between communication management and disaster avoidance.

The research questions are as follows: how does communication management impact disaster avoidance and the organizational communication climate in the oil and gas industry? Does the organizational communication climate have a significant impact on disaster avoidance? Does the organizational communication climate mediate the relationship between communication management and disaster avoidance?

This article aims to answer these research questions. First, we will describe and provide arguments from past literature related to disaster and hazards in the oil and gas industry, communication management, disaster avoidance and the organizational communication climate. Based on this discussion, we will develop the framework and hypotheses of this study. In the methodology section, we will identify the method and analysis used to conduct this study and present findings from the pilot study. This will be followed by a presentation of our results and hypotheses testing. The next section includes a discussion based on the findings and testing of our hypotheses. Finally, we will present the conclusion, limitations of the study, and future recommendations.

\section{Literature Review}

\subsection{Hazards in the Oil and Gas Industry}

The oil and gas industry is one of the most hazardous industries in the world. The high-risk activities associated with the industry, as well as the possibilities for a single incident to turn into a natural disaster, make safety issues vitally important in the field. Notable examples of such disasters are the Deepwater Horizon rig, the Exxon Valdez tanker and the BP Texas City refinery. As such, the discussion of hazards in the oil and gas industry always includes elements such as safety measures. Multiple studies have been conducted addressing the issues of hazards and safety in the oil and gas industries. Lilburne, Lant and Hassal [20] identified that experience plays an important role for workers when making a decision related to safety issues. They further suggested that the workers would benefit from more information, in which regard communication would be the crucial facilitator. In another study, it was shown that there is a conflict between risk and safety perceptions and production demand. In a study on oil and gas workers in Russia, Korneeva and Simonova [21] showed that factors such as production targets and the competencies expected of them affect workers' perceptions of a hazardous action. Table 1 shows a structured review of studies related to hazardous incidents in the oil and gas industry.

\subsection{Safety Communication}

Safety communication guides and motivates workers to commit to safety and reduce the chances of incidents in the workplace [25]. Acar and Acar [26] emphasize that safety communication procedures help to improve workplace safety practices. Safety rules and guidelines, for example, are considered as written communications for employees [27]. Vatanparast, [8] for instance, found that every incident in the industry has been related to communication errors that occurred during shift handovers. Safety communication procedure during the shift handover is crucial [7], as it could be a contributing factor to major incidents. A study reported that even though startup, shutdown and changeover comprise less than $5 \%$ of the activity at the plants, $40 \%$ of the recorded incidents take place during this time [8]. Besides this finding, in a study conducted to investigate safety challenges in the Oman water sector, it was identified that despite the fact there are regulations related to safety, the workers do not always put safety first during production and operation [28]. Thus, there is a definite need for proper safety communication. 
Table 1. Structured review on studies related to hazardous incidents in the oil and gas industry.

\begin{tabular}{|c|c|c|c|}
\hline Place of Study & Subject of Study & Summary Key Findings & Sources \\
\hline South and North Russia & $\begin{array}{l}\text { Employee psychological } \\
\text { safety features }\end{array}$ & $\begin{array}{c}\text { Psychological features related to safety } \\
\text { are subjected to geographical region } \\
\text { and the location of the oil and gas } \\
\text { operation }\end{array}$ & [21] \\
\hline $\begin{array}{l}\text { Offshore within the Arctic } \\
\text { Region }\end{array}$ & $\begin{array}{l}\text { Case study on past hazardous } \\
\text { incidents related to oil and gas } \\
\text { operation }\end{array}$ & $\begin{array}{c}\text { Natural hazards are one of the major } \\
\text { problems in the Arctic region. Safety } \\
\text { management is one of the strategies to } \\
\text { ensure a "zero accidents" policy can be } \\
\text { achieved }\end{array}$ & {$[4]$} \\
\hline $\begin{array}{l}\text { Oil and gas utility companies } \\
\text { in Pakistan }\end{array}$ & $\begin{array}{l}\text { Behavior-based safety in } \\
\text { reducing hazardous accidents. }\end{array}$ & $\begin{array}{l}\text { The workload is a major factor } \\
\text { associated with safety negligence. } \\
\text { Employee knowledge associated with } \\
\text { safety measures can be improved } \\
\text { through proper programs and courses }\end{array}$ & [22] \\
\hline $\begin{array}{l}\text { Iranian petrochemical } \\
\text { companies }\end{array}$ & Unsafe work behavior & $\begin{array}{l}\text { Workers who are exposed to } \\
\text { condescending safety supervision and } \\
\text { workplace bullying are more likely to } \\
\text { engage in risky and unsafe behaviors, } \\
\text { which leads to a high } \\
\text { probability of hazardous incidents }\end{array}$ & [23] \\
\hline $\begin{array}{l}\text { Malaysia oil and gas } \\
\text { companies }\end{array}$ & $\begin{array}{l}\text { Non-compliance with safety } \\
\text { regulation }\end{array}$ & $\begin{array}{l}\text { Financial limitations, an insufficient } \\
\text { workforce, and lack of supervision } \\
\text { might contribute to safety negligence } \\
\text { and hazardous incidents }\end{array}$ & [24] \\
\hline
\end{tabular}

According to Shohet et al. [29], there is a need to integrate communication approaches in managing safety among employees. Besides using a technological approach, such as integrated communication devices in various forms to enhance communication capacity and capability $[29,30]$, the management of safety communication is also crucial. Well-developed communications management systems should entail safety communication in a paramount position, from which communication should encourage the process of exchanging information between personnel [31]. Furthermore, communications management provides a space for interaction and a discussion platform for changing ideas and discussing safety issues. Thus, the first hypothesis of the study is:

Hypothesis 1 (H1). Communication management has an impact on disaster avoidance.

However, the issue encapsulating safety communication revolves around the direction of communication in the organization. In a common communication direction, the management will oversee and supervise the adherence to safety regulations. Despite that, studies have shown that there is a possible conflict between management policy and management actions [32]. This conflict could undermine employee trust and thus lead to incompliance with safety regulations in the organization. Therefore, in nurturing a balanced and comprehensive safety climate, attention should be given to improving communication management and capacity.

For instance, in a study conducted in Saudi Arabia, it was found that communication is an essential influencing factor that contributes to a better safety climate in the construction industry [33]. Moreover, it was argued that a dynamic internal communication system is vital in a high-risk industry such as oil and gas, as it will allow a lower attrition rate among the workers [34]. Hence, it is important for an organization's climate to have a proper communication mechanism. The communication mechanism will facilitate the flow of information as well as the resolution of disputes related to safety and disaster avoidance. Thus, the second hypothesis of this study is: 
Hypothesis 2 (H2). Communication management has an impact on the organizational communication climate.

\subsection{Organizational Communication Climate}

The definition of an organizational climate refers to the "relatively enduring quality of the internal environment of the organization that (a) is experienced by its members, (b) influences their behavior, and (c) can be described in terms of values of a particular set of characteristics (or attributes) of the environment" [35]. The internal environment plays an important role in the relationship between the organization leaders and the other organization members. Effective communication between these two parties is argued to nurture the development of a collaborative communication climate, in which its role is significant to enhance compliance with safety regulations [18]. The leader's role is essential in this area. According to a study conducted among workers in the United States, supportive communication from leaders toward the workers stimulates symmetrical communication in the organization [36]. Symmetrical communication is required to foster and improve communication mechanisms in the organizational climate. The findings from the study further indicated that a well-equipped communication mechanism leads to employee creativity [36]. A similar organizational communication climate could be applied in terms of safety commitment and disaster avoidance.

Apart from the communication mechanisms, leaders play a significantly important role in directing employees for safety improvement practices. The leaders need to motivate workers to accomplish safety tasks and meet the challenges, to maintain safety commitment [37]. Leadership commitment is a process of communication and interaction between the leaders and the workers, by showing concern for their welfare, to attain the highest level of safety commitment in avoiding incidents and disasters [38]. Opening up the climate to two-way communication could, however, be a major challenge to an engineer when assuming a managerial role [39].

As engineers are trained to be task-oriented and highly technical, training such employees in people skills, i.e., communication skills, can be challenging, especially when managing safety-related matters and conflicts among the employees, and across the departments, to maintain a supportive climate. This is especially necessary when communicating with personnel from various levels and specialisms, i.e., management, executives, nonexecutives and technical staff. Employees in the oil and gas industry must put safety as a top priority. Failure and ineffective communication could be fatal, resulting in loss of life and manpower [8].

Safety-related communication management between leaders and employees can hence have a significant impact on an employee's safety commitment [40] to avoiding disasters and incidents. Safety communication management comes in varying forms, including policies and procedures, performance statistics, hazard and incident reports, workplace inductions, risk assessments, and training. The information must be presented by the organization leaders and management in a manner that recipients can understand [15]. Recognizing language implications at such levels of communication is also essential, to ensure that all employees have a shared mission and vision of the organization [41,42]. Therefore, the third hypothesis for this study is:

Hypothesis 3 (H3). The organizational communication climate has an impact on disaster avoidance.

The choices and the usage of words in communication shape the perceptions formed by individuals [43]. Such choices of language and words have a profound influence on the outcome of safety communications [16]. Specifically, communication strategies are employed by speakers, particularly when communication breaks down $[44,45]$. The choice of language and words can have a profound influence on the outcome of safety communications. The management teams of the organization and at the plants have the primary responsibility for the establishment of a positive communication climate within the organization. "Climate" is a well-established term in the field of communication that 
has long been defined as the "relatively enduring quality of the internal environment of the organization that is experienced by its members, [ ... ] influences their behavior, and [ ... ] can be described in terms of values of a particular set of characteristics (or attributes) of the environment" [46].

The climate thus sets an atmosphere in the organization that either encourages or discourages communication. Organizations with supportive environments encourage worker participation, the free and open exchange of information, and constructive conflict resolution. In organizations with a defensive climate, employees keep their views to themselves, make only guarded statements, and suffer from reduced morale. Thus, effective communication is important for the establishment of a collaborative communication climate.

Safety commitment is essential to avoid incidents and disasters and requires the involvement of every individual employee. Commitment to incident and disaster avoidance could improve workplace safety if every individual followed the organizational safety goals and was willing to improve safety performance [47]. Safety commitment is vital, which contributes to the intensity of employees to determine company initiatives and develop personal approaches toward workplace safety [48]. Safety commitment in the workplace at the individual level is associated with behavior and attitude [19]. The leadership way of communication influences employees' motivation to maintain safe practice. Numerous studies have discussed the importance of safety commitment for workplace safety performance [14]. Hence, the fourth hypothesis of this study is:

Hypothesis 4 (H4). The organizational communication climate has a mediating impact on the relationship between communication management and disaster avoidance.

The framework of this study is shown in Figure 1 below.

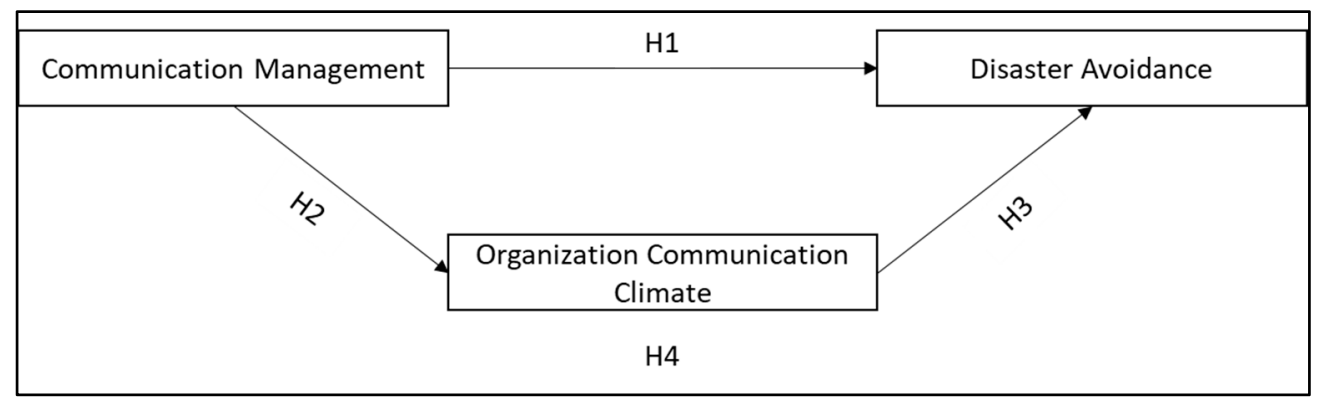

Figure 1. Conceptual framework of the study.

\section{Methodology}

This study is based on a quantitative research design in addressing the developed research questions. As the context of this study is on disaster avoidance in oil and gas plants, the respondents were the technical employees, executives, and management personnel of oil and gas industry facilities in Malaysia. Questionnaires were disseminated as an instrument for data collection in this study. The following section discusses the items used in the instrument.

\subsection{Measurement}

The questionnaire used in this study was designed based on a number of studies conducted on organizational communication climates, communication management and disaster avoidance. The questionnaire employed a 5-point Likert scale to record the responses given by the respondents. There are 7 items to measure communication management, which were adapted from Vinodkumar and Bhasi [49], 7 items to measure the organizational communication climate, which were adopted from Micheal et al. [50], and the final 7 items were adopted from Sodarni [51] to measure the disaster avoidance construct. 


\subsection{Sampling}

Based on the calculation of a sample size to meet the statistical power requirement, as assessed by the G-power sample size calculation software, the minimum sample required is 217 [52]. However, 260 respondents were involved in the study. Purposive sampling was employed, as this study required specific technical skills, and the respondents had to be active workers in the oil and gas industry. The study was conducted at several oil and gas facilities across several companies in Malaysia. Purposive sampling was employed to ensure that the respondents fulfilled the research requirement.

\subsection{Pilot Study}

Prior to full-scale data collection, a pilot study was conducted to test the reliability and validity of the questionnaire used. 50 respondents who have experience of working in oil and gas facilities were involved in this pilot study. The Cronbach's alpha score and composite reliability score were used as a measurement for identifying the internal consistency among the items used. Each construct showed a reliability score of more than 0.7 , indicating that the instrument used was reliable [53].

\subsection{Data Analysis}

The responses collected from the respondents were first screened for missing data. The data were then analyzed for demographic and descriptive findings using descriptive statistics. For this study, we used partial least square-structural equation modeling (PLSSEM) for inferential statistics and hypotheses testing [54,55]. Before the hypotheses testing, which comprised structural model assessment, we evaluated the needs of the measurement model. There were three required assessments: internal consistency reliability, convergent validity, and discriminant validity [56]. Findings from the first and second assessments are shown in Table 2.

Table 2. Cronbach's alpha, composite reliability and average variance extraction (AVE) for each construct.

\begin{tabular}{cccc}
\hline Construct & Composite Reliability & $\begin{array}{c}\text { Reliability (Cronbach Alpha } \\
\text { Score) }\end{array}$ & $\begin{array}{c}\text { Average Variance Extraction } \\
\text { (AVE) }\end{array}$ \\
\hline $\begin{array}{c}\text { Communication Management } \\
\text { Organizational Communication } \\
\text { Climate }\end{array}$ & 0.834 & 0.862 & 0.673 \\
$\begin{array}{c}\text { Disaster Avoidance (Safety } \\
\text { Commitment) }\end{array}$ & 0.853 & 0.837 & 0.612 \\
\hline
\end{tabular}

All constructs show a composite reliability score between 0.7 and 0.9 , indicating internal consistency and an average variance extraction (AVE) score of more than 0.5, indicating that the construct explains $50 \%$ of the variance of its item [57]. Additionally, the heterotrait-monotrait (HTMT) test was conducted to assess the discriminant validity of the instrument, obtaining a score of less than 1 for each construct, indicating high discriminant validity [56].

We also included academic qualifications as the control variable in this study. We tested the relationship between academic qualifications and both the organizational communication climate and disaster avoidance. The findings showed that academic qualifications did not have a significant relationship with the organizational communication climate $(\beta=0.031, t$-test $=0.63, p=0.191)$ and disaster avoidance $(\beta=0.082, t$-test $=0.103, p=0.167)$.

\section{Results}

\subsection{Demographic}

The demographical analysis shows that the majority of the respondents were male $(95 \%)$. The majority of them were also in the age group between 30 and 50 years old $(72.7 \%)$. Furthermore, $60 \%$ of the respondents had been working for more than 10 years in the oil and gas industry. If we turn our attention toward workplace accidents, more 
than $80 \%$ mentioned that they had never encountered workplace accidents. However, $40 \%$ of the respondents acknowledged that there were near-miss cases that happened at their workplace. Details on the demographic study are shown in Table 3.

Table 3. Demographic statistics of respondents $(n=260)$.

\begin{tabular}{|c|c|c|}
\hline \multicolumn{2}{|c|}{ Category } & \multirow{3}{*}{$\begin{array}{c}\text { Percentage (\%) } \\
95 \\
5\end{array}$} \\
\hline & Male & \\
\hline Gender & Female & \\
\hline \multirow{4}{*}{ Age } & $20-29$ & 18.8 \\
\hline & $30-39$ & 38.5 \\
\hline & $40-49$ & 34.2 \\
\hline & 50 and above & 8.5 \\
\hline \multirow{4}{*}{$\begin{array}{l}\text { Highest Academic } \\
\text { Qualification }\end{array}$} & Certificate & 56.9 \\
\hline & Diploma & 23.1 \\
\hline & Bachelor's degree & 17.3 \\
\hline & Master's/Ph.D. & 2.7 \\
\hline \multirow{2}{*}{ Current Designation } & Executive & 22.3 \\
\hline & Non-executive & 77.7 \\
\hline \multirow{5}{*}{ Working Experience (Years) } & Less than 2 & 4.2 \\
\hline & $2-5$ & 9.6 \\
\hline & $6-10$ & 26.2 \\
\hline & $11-15$ & 14.6 \\
\hline & More than 15 & 45.4 \\
\hline \multirow{4}{*}{ Workplace Accident } & No & 80.8 \\
\hline & $1-2$ times & 12.3 \\
\hline & $3-5$ times & 5 \\
\hline & More than 5 times & 1.9 \\
\hline \multirow{2}{*}{ Near Misses Incident } & Yes & 40.4 \\
\hline & No & 59.6 \\
\hline
\end{tabular}

\subsection{Descriptive Analysis}

Table 4, presented below, shows the mean scores, standard deviation, and factor loadings for all the items used in the study. Overall, the findings suggest that the respondents were satisfied with communications by the management (mean $=4.01, \mathrm{SD}=0.539$ ). Specifically, it shows that management always communicated well about safety and health issues that were practically relevant to the organization (mean score $=4.21$ ), especially in meetings (mean score $=4.28$ ), and the respondents could obtain safety information from the company (mean score $=4.10$ ).

Furthermore, regarding the organizational communication climate, the findings indicated that the respondents knew how they could communicate with their supervisors (mean score $=4.00$ ). Regarding disaster avoidance, our study found that the respondents agreed that it was very important to work in a safe environment (mean score $=4.54$ ). They were very cooperative with their supervisor/manager about safety issues (mean score $=4.45$ ). Besides these findings, the respondents cared about the safety rules and regulations in their workplace (mean score $=4.26$ ) and were willing to obey the regulations to keep their workplace safe (mean score $=4.35$ ). 
Table 4. Descriptive analysis of the study.

\begin{tabular}{lccc}
\hline \multicolumn{1}{c}{ Description/Item } & Mean Score & Standard Deviation & Factor Loading (CFA) \\
\hline $\begin{array}{l}\text { Communication Management } \\
\begin{array}{l}\text { Safety issues are included in } \\
\text { communication meetings. }\end{array}\end{array}$ & 4.28 & 0.649 & 0.834 \\
$\begin{array}{l}\text { Relevant safety and health issues are } \\
\text { always communicated. }\end{array}$ & 4.21 & 0.613 & 0.772 \\
$\begin{array}{l}\text { I am informed of the outcomes of safety } \\
\text { and health meetings. }\end{array}$ & 3.88 & 0.731 & 0.751 \\
$\begin{array}{l}\text { I can get safety information from the } \\
\text { company. }\end{array}$ & 4.10 & 0.567 & 0.803 \\
$\begin{array}{l}\text { Management operates an open-door } \\
\text { policy on safety issues. }\end{array}$ & 3.85 & 0.800 & 0.812 \\
$\begin{array}{l}\text { There is sufficient opportunity to discuss } \\
\text { and deal with safety issues in my } \\
\text { organization meetings. }\end{array}$ & 3.86 & 0.748 & 0.771 \\
$\begin{array}{l}\text { There is open communication about } \\
\text { safety issues in this workplace. }\end{array}$ & & 3.88 & 0.794
\end{tabular}

\section{Organizational Communication Climate}

My supervisor communicates with me about my job-related problems and

needs.

I know how I can communicate with my supervisor.

My supervisor informs me of my potential.

My supervisor would use all means of communication to help me solve

work-related problems.

My supervisor would use all means of communication to "bail me out" even

though it was at his/her expense.

I exchange information about my

supervisor's decisions when he/she is

not present to do so.

I feel comfortable discussing safety issues with my supervisor.

0.667

0.825

\section{Disaster Avoidance (Safety Commitment)}

\begin{tabular}{llll}
$\begin{array}{l}\text { It is very important to work in a safe } \\
\text { environment. }\end{array}$ & 4.54 & 0.604 & 0.841 \\
$\begin{array}{l}\text { I cooperate with my supervisor/manager } \\
\text { about safety issues. }\end{array}$ & 4.45 & 0.704 & 0.792 \\
$\begin{array}{l}\text { I really care about the safety procedures } \\
\text { and regulations at my workplace. }\end{array}$ & 4.26 & 0.602 & 0.819 \\
$\begin{array}{l}\text { I would like to obey the safety } \\
\text { regulations in order to keep my }\end{array}$ & 4.35 & 0.707 & 0.810 \\
$\begin{array}{l}\text { workplace safe. } \\
\begin{array}{l}\text { I will ensure the risks are assessed before } \\
\text { starting my work. }\end{array}\end{array}$ & 4.24 & 0.580 & 0.738 \\
$\begin{array}{l}\text { I always ensure that the safety equipment } \\
\text { is working properly before I start a job. }\end{array}$ & 4.37 & 0.577 & 0.883 \\
$\begin{array}{l}\text { I am willing to put in great effort to } \\
\text { achieve safety goals. }\end{array}$ & 4.24 & 0.589 & 0.765 \\
\hline
\end{tabular}

\subsection{Hypothesis Testing}

Three different tests were conducted to test the hypotheses. First, the predictive power of the relationship was measured using $\mathrm{R}^{2}$, to measure the variance explained in 
each endogenous construct (i.e., the dependent variable). The second test measured the statistical significance of each relationship through bootstrapping [58]. A $p$-value of less than 0.05 , and a $\mathrm{T}$ score of more than 1.96 , is considered a statistically significant relationship; hence, the hypotheses should be accepted. The details of the findings are shown in Table 5. The findings indicate that communication management has a significant impact on disaster avoidance and the organizational communication climate. The organizational communication climate has a significant impact on disaster avoidance.

Table 5. Construct relationship and hypotheses testing.

\begin{tabular}{lcccc}
\hline \multicolumn{1}{c}{ Hypotheses } & Std Beta & $\begin{array}{c}\text { T Statistics } \\
\text { (IO/STDEV I) }\end{array}$ & $p$ Values & Hypotheses Testing \\
\hline $\begin{array}{l}\text { H1: Communication Management }->\text { Disaster } \\
\text { Avoidance }\end{array}$ & 0.531 & 4.212 & $<0.001$ & Supported \\
\hline $\begin{array}{l}\text { H2: Communication Management -> } \\
\begin{array}{l}\text { Organizational Communication Climate } \\
\text { H3: Organizational Communication Climate }-> \\
\text { Disaster Avoidance (Safety Commitment) }\end{array}\end{array}$ & 0.589 & 4.705 & $<0.001$ & Supported \\
\hline
\end{tabular}

\subsection{Assessment of the Mediation Analysis}

The mediation models were tested to examine the indirect effects of the organizational communication climate on the relationship between communication management on disaster avoidance. The bootstrapping analysis has shown that the indirect effects are significant. The mediation assessment is as follows: $\beta 1=0.339(t$-values $=3.685)$

The indirect effects (95\% Boot CI Bias Corrected: $\beta 1(\mathrm{LL}=0.156, \mathrm{UL}=0.542)$ show that each upper level (UL) and lower level (LL) of each relationship do not straddle 0 in between, indicating that there is a mediation in the relationship [56,59]. Table 6 shows the detail of the mediation analysis, while Figure 2 indicates the final findings of the relationship examined in the study. Hence, the fourth hypothesis is supported.

Table 6. Result of the mediation analysis.

\begin{tabular}{cccc}
\hline Mediating Relationship & Std Beta & $p$ Values (Significance Level) & Hypothesis Testing \\
\hline $\begin{array}{c}\text { H4: Communication Management }-> \\
\text { Organizational Communication }\end{array}$ & 0.339 & $<0.001$ & Supported \\
Climate $->$ Disaster Avoidance $(\beta 1)$ & & & \\
\hline
\end{tabular}

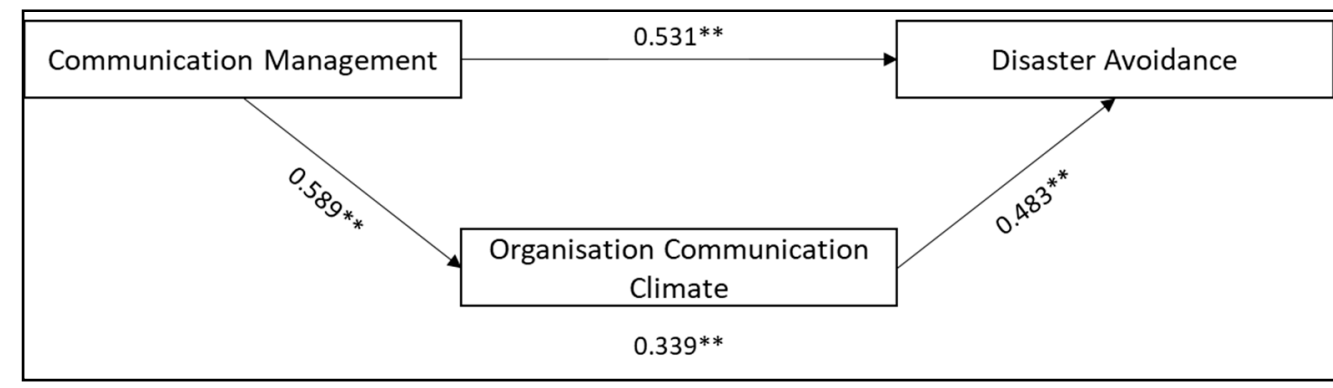

Figure 2. Result of the relationship examined in the study. ${ }^{* *} p<0.001$.

\section{Discussion}

This study seeks to investigate the impact of both communication management and the organizational communication climate on disaster avoidance in the oil and gas industry. In achieving that, we developed four hypotheses and tested them. Based on the findings, this indicates that all four hypotheses are supported.

Discussion on $\mathrm{H} 1$ - Communication management has an impact on disaster avoidance. 
The first hypothesis of this study showed that communication management has an impact on disaster avoidance. It indicated that, although safety regulations and preventive measures through a routinized approach are essential, proper communication management is also crucial. Communication, in this case, includes safety information that is disseminated regularly to the workers, of which they are reminded frequently during a meeting, briefing or any other platform.

An ill-equipped communication platform could lead to misinformation that consequently causes disaster, especially in a high-risk environment such as the oil and gas industry. Our findings are similar to those of a study conducted by Dahl and Kongsvik, where they reported that workers in the oil and gas industry are committed to safety practices and disaster avoidance when the management can communicate openly and constantly emphasize the importance of safety regulations in the industry [38].

It also mirrored the findings of safety regulations in other industries. For instance, researchers showed that improved communication management through integration with mobile applications facilitates safety adherence by workers in the construction industry [29]. Hence, it is proven that communication management is crucial as it is the main vehicle for disseminating information relating to safety issues, which is essential for disaster avoidance.

Discussion on $\mathrm{H} 2$ - Communication management has an impact on the organizational communication climate.

The second hypothesis in which communication management has an impact on organizational communication climate is also supported. The key factor in nurturing a positive communication climate in an organization is having a systematic information flow [60]. Through proper communications management, the process of information circulation within an organization can be streamlined according to its specific objectives or functions.

Consequently, any information barriers can be overcome. Furthermore, noise-related issues that were notorious for hindering information transfer and knowledge-sharing could be reduced [61]. This is crucial, especially in a high-risk work environment such as the oil and gas industry, where disasters and accidents can happen if the information is not properly transmitted among the workers. This has been similarly reported in various other studies where the systematic management of information is highlighted; miscommunication is frequently reported as one of the main causes of accidents in the oil and gas industry $[62,63]$.

Furthermore, previous studies have highlighted the primary function of communication among peers in nurturing an organizational communication climate [61]. Peer communication is also an important part of communication management. The ability of communication management to promote information-sharing, as well as increasing transparency and openness in communication, enables workers to constantly remind each other of issues; this reflects a good organizational climate, especially related to avoiding calamities in the working environment.

Discussion on H3-Organizational communication climate and disaster avoidance.

The third hypothesis of this study has been proven, in that the organizational communication climate does have an impact on disaster avoidance in the oil and gas industry. As discussed earlier, a positive organizational communication climate is indicated by consistent information flow in the organization, bypassing barriers such as noise [60]. Thus, having constant and consistent information is paramount in disaster avoidance. An organization that constantly and consistently emphasizes the importance of information-sharing between workers concerning safety matters, such as work schedule or machinery breakdown, will be able to minimize workplace accidents in even the most hazardous workplace.

This study is in line with the findings from a study conducted in the Canadian oil and gas industry. The study reported that a firm and rule-oriented leadership, which is the main component for a good organizational climate, fostered strong compliance with rules and good safety behavior in the workers [64]. Furthermore, in another study, the researchers 
found that strong leaders will influence workers to cultivate positive communication, thus contributing to enhancing workers' commitment in regard to safety and disaster avoidance [18].

In contrast, negligence and information blocks, which reflect a bad organizational communication climate, could lead to potential disasters and accidents. This has been similarly reported in other studies. For instance, lack of information sharing has been blamed for several cases of dust explosions in powder-manufacturing industries in Malaysia and China [65]. Furthermore, an infertile communication climate in an organization has led to improper planning, overlapping schedules and conflict escalation in the workplace [66]. These are among the factors that could contribute to an increase in workplace accidents.

Discussion on H4-Mediating the impact of the organizational communication climate.

The fourth hypothesis of our study regarded identifying the mediating impact of a communication climate, which has been proven to have a statistically significant mediating impact on the relationship between communication management and disaster avoidance. One of the key factors that lead to disaster avoidance is employee compliance and their commitment to safety [51]. In order to cultivate such a working culture, attention needs to be given to promoting communication and information-sharing.

Thus, this study highlighted that the functionality and working mechanisms of communication in promoting worker's safety compliance can be explained by the organization's communication climate. According to Lantera (2019), workers' behavior depends on how information is being delivered to them, especially by their leaders. Information coming from an unprofessional supervisor might not be treated seriously, which portrays a bad organizational communication climate.

Similarly, the inability of the management to emphasize the seriousness and importance of workplace safety can contribute to a non-compliance attitude in workers [61]. Compliance is crucial in a high-risk environment like the oil and gas industry, where the risk of accidents is high. Hence, it is imperative to highlight the mediating impact of a good organizational communication climate when explaining the relationship between communication management and disaster avoidance.

Moreover, the capability of an organizational communication climate depends on the leader-member exchange in the context of this study. As this is proven to be the significant mediator that explains the relationship between communication management and disaster avoidance, the industry should allocate more resources to strengthen its organizational communication climate. Multiple strategies can be adopted, including creating an integrated communication control involving multiple devices and the Internet of Things (IoT). This application has been tested and proven to be beneficial for other industries, such as construction, in promoting good safety behavior among the workers [29]. It can likewise be applied in the oil and gas industry.

\section{Conclusions}

The findings of this study extend empirical evidence for previous research in the context of disaster avoidance in the oil and gas industry. First, the findings demonstrate that communication management could impact the organizational communication climate. They emphasize elements such as constant information transfer and openness in communication, throughout the whole organizational structure.

These findings reduce the gap in previous studies, where the role of communication management was proven to influence conflict resolution [18,67]. Moreover, this study also reported that the organizational communication climate is the mediating element that explains the relationship between communication management and disaster avoidance in the oil and gas industry. It links the interrelationship between the three elements, which highlights its importance in overcoming man-made disasters and catastrophes in the oil and gas industry. 
The findings from this study will not only contribute to the discourse in the context of disaster avoidance and safety management in the oil and gas industry but will also benefit practitioners and policymakers. For instance, this study indicated that an organizational communication climate is important and that it could be enhanced through management and supervisor commitment.

The importance of management and supervisor commitment could be viewed from the perspective of employees' welfare. Communicating with them as a way to achieve safety goals alone is insufficient. The management needs to increase the social relationships and interaction with their employees. One avenue is through conducting social activities, such as team building, and through corporate social responsibility (CSR) programs. In doing so, they could gain the trust, loyalty and cooperation from their employees that will then translate to a better organizational communication climate and disaster avoidance.

\section{Limitations and Future Recommendation}

The first limitation of this study is its focus on organizational scale, and it does not investigate individual factors, such as reticence, as a hindrance to communication. Several studies have highlighted that, despite working in a positive organizational climate, a person may still choose to be reticent and may tend to be reserved in communication and when sharing information $[68,69]$. Thus, future studies need to investigate the impact of being reticent about disaster avoidance on the organizational communication climate.

Next, this study does not include working experience as a factor that might affect communication management, climate and disaster avoidance. Having worked too long in an organization or industry might have both positive and negative effects. From a positive perspective, workers tend to be more experienced and familiar with the risks and the related information. However, the workers might become too comfortable with the working environment and take chances. Furthermore, as they already understand the details of the workplace, non-compliance behavior might occur. Therefore, future studies need to investigate the impact of working experience on all communication management, climate and disaster avoidance factors.

In addition, as the communication approach is becoming more advanced in IR 4.0, the introduction of new technology, such as new media, artificial intelligence, and augmented reality, is emerging. These technologies could have an impact on the communication relationship between the organization and its workers. This study does not investigate the capability of such elements. Henceforth, future studies shall explore the impact of technological elements on communication management, organizational climate and disaster avoidance in the oil and gas industry.

Author Contributions: Conceptualization, S.M.N. and A.R.A.R.; methodology, A.R.A.R.; resources, S.M.N., R.C.O. and U.P.; writing-original draft preparation, A.R.A.R. and S.M.N.; writing-review and editing, S.M.N., R.A.R. and R.C.O.; funding acquisition, S.M.N., R.C.O. and U.P. All authors have read and agreed to the published version of the manuscript.

Funding: This research was funded by International Joint Research Project, grant number 015ME0192. The APC was funded by the same grant.

Institutional Review Board Statement: Ethical review and approval was not required for the study on human participants in accordance with the local legislation and institutional requirements.

Informed Consent Statement: Informed consent was obtained from all subjects involved in the study.

Data Availability Statement: The data presented in this study are available on request from the corresponding author.

Acknowledgments: We would like to thank all personnel and organizations that contributed directly or indirectly to the study. We also would like to thank anonymous reviewers for the input given in enhancing the quality of this article.

Conflicts of Interest: The authors declare no conflict of interest. 


\section{References}

1. MIDA. Malaysia Investment Development Authority Oil and Gas Outlook in Malaysia; MIDA: Putrajaya, Malaysia, 2015.

2. Bevilacqua, M.; Bottani, E.; Ciarapica, F.E.; Costantino, F.; Di Donato, L.; Ferraro, A.; Mazzuto, G.; Monteriù, A.; Nardini, G.; Ortenzi, M.; et al. Digital Twin Reference Model Development to Prevent Operators' Risk in Process Plants. Sustainability 2020, 12, 1088. [CrossRef]

3. Alkhaldi, M.; Pathirage, C.; Kulatunga, U. The Role of Human Error in Accidents within Oil and Gas Industry in Bahrain. In Proceedings of the 13th International Postgraduate Research Conference (IPGRC), Salfor, UK, 14-15 September 2017.

4. Necci, A.; Tarantola, S.; Vamanu, B.; Krausmann, E.; Ponte, L. Lessons learned from offshore oil and gas incidents in the Arctic and other ice-prone seas. Ocean Eng. 2019, 185, 12-26. [CrossRef]

5. Tang, D.K.H.; Leiliabadi, F.; Olugu, E.U.; Dawal, S.Z.M. Factors affecting safety of processes in the Malaysian oil and gas industry. Saf. Sci. 2017, 92, 44-52. [CrossRef]

6. Øien, K.; Utne, I.; Herrera, I. Building Safety indicators: Part 1-Theoretical foundation. Saf. Sci. 2011, 49, 148-161. [CrossRef]

7. Brazier, A.; Pacitti, B. The Link between Safety and Shift Handover. In Proceedings of the Society of Petroleum EngineersOffshore Europe Oil and Gas Conference and Exhibition, Aberdeen, UK, 6-8 September 2011; OE 2011. Volume 2.

8. Vatanparast, S. EHS Today; Endeavor Business Media: Nashville, TN, USA, 2019.

9. Ismail, M. Corporate Social Responsibility and Its Role in Community Development: An International Perspective. J. Int. Soc. Res. 2009, 2.

10. Fatin, A.; Desa, N.C.; Habidin, N.F.; Hibadullah, S.N.; Fuzi, N.M. The Impact of Occupational Safety and Health Administration Practices (OSHAP) and OHSAS 18001: Efforts in Malaysian Automotive Industry. J. Appl. Sci. Res. 2013, 1, 47-59.

11. Sklet, S. Hydrocarbon releases on oil and gas production platforms: Release scenarios and safety barriers. J. Loss Prev. Process. Ind. 2006, 19, 481-493. [CrossRef]

12. Abdallah, A.M.; Zuraida, H.; Jamal, A.M. A Conceptual Framework for Upgrading Safety Performance by Influence Safety Training, Management Commitment to Safety and Work Environment: Jordanian Hospitals. Int. J. Bus. Soc. Res. 2018, 8, 25-35. [CrossRef]

13. Amirah, N.A.; Asma, W.I.; Muda, M.S.; Amin, W.A.A.W.M. Safety Culture in Combating Occupational Safety and Health Problems in the Malaysian Manufacturing Sectors. Asian Soc. Sci. 2013, 9, 9. [CrossRef]

14. Eklof, M.; Ahlborg, G., Jr. Improving communication among healthcare workers: A controlled study. J. Work. Learn. 2016, 28, 81-96. [CrossRef]

15. Vecchio-Sadus, A.; Griffiths, S. Marketing strategies for enhancing safety culture. Saf. Sci. 2004, 42, 601-619. [CrossRef]

16. Cole, K. Crystal Clear Communication: Skills for Understanding and Being Understood; Pearson Education Australia: Brisbane, Australia, 2000; ISBN 0724805389.

17. Bakas, D.; Kostis, P.; Petrakis, P. Culture and labour productivity: An empirical investigation. Econ. Model. 2019, 85, 233-243. [CrossRef]

18. Nordin, S.M.; Sivapalan, S.; Bhattacharyya, E.; Ahmad, H.H.W.F.W.; Abdullah, A. Organizational Communication Climate and Conflict Management: Communications Management in an Oil and Gas Company. Procedia Soc. Behav. Sci. 2014, 109, 1046-1058 [CrossRef]

19. Ertürk, A.; Broeck, H.V.D.; Verbrigghe, J. Self-other agreement on transformational leadership and subordinates' assessment of supervisor's performance. Leadersh. Organ. Dev. J. 2018, 39, 291-308. [CrossRef]

20. Lilburne, C.M.; Lant, P.A.; Hassall, M.E. Exploring oil and gas industry workers' knowledge and information needs. J. Loss Prev. Process. Ind. 2021, 72, 104514. [CrossRef]

21. Korneeva, Y.A.; Simonova, N.N. Psychological safety of oil and gas workers in the South and North of the Russian Federation. In Proceedings of the Society of Petroleum Engineers-SPE Russian Petroleum Technology Conference, RPTC 2020, Moscow, Russia, 25-29 October 2020. [CrossRef]

22. Hussain, U.; Shoukat, M.H.; Haider, M.S. Analysis of safety awareness, accident prevention and implementation of behavior based safety program in energy utility. In Proceedings of the 2019 6th International Conference on Frontiers of Industrial Engineering, ICFIE 2019, London, UK, 10-12 September 2019; pp. 84-88. [CrossRef]

23. Harsini, A.Z.; Ghofranipour, F.; Sanaeinasab, H.; Shokravi, F.A.; Bohle, P.; Matthews, L.R. Factors associated with unsafe work behaviours in an Iranian petrochemical company: Perspectives of workers, supervisors, and safety managers. BMC Public Health 2020, 20, 1-13. [CrossRef]

24. Tarudin, N.F.; Kordi, N.E.; Aziz, T.N.A.T.; Adlan, M.A.A. The inclination of oil and gas supply base personnel towards safety compliance. In Proceedings of the AIP Conference Proceedings, Maharasthra, India, 5-6 July 2018; pp. 1-7.

25. Nelson, K. Are Civility and Candor Compatible? Examining the Tension between Respectful and Honest Workplace Communication. Ph.D. Thesis, University of Connecticut, Storrs, CT, USA, 2019.

26. Acar, A.; Acar, P. Organizational Culture Types and Their Effects on Organizational Performance in Turkish Hospitals. EMAJ Emerg. Mark. J. 2014, 3, 18-31. [CrossRef]

27. Huang, Y.-H.; Sinclair, R.R.; Lee, J.; McFadden, A.C.; Cheung, J.H.; Murphy, L.A. Does talking the talk matter? Effects of supervisor safety communication and safety climate on long-haul truckers' safety performance. Accid. Anal. Prev. 2018, 117, 357-367. [CrossRef] 
28. Al Mawli, B.; Al Alawi, M.; Elazouni, A.; Al-Mamun, A. Construction SMEs safety challenges in water sector in Oman. Saf. Sci. 2021, 136, 105156. [CrossRef]

29. Shohet, I.M.; Wei, H.-H.; Skibniewski, M.J.; Tak, B.; Revivi, M. Integrated Communication, Control, and Command of Construction Safety and Quality. J. Constr. Eng. Manag. 2019, 145, 04019051. [CrossRef]

30. Dai, F.; Olorunfemi, A.; Peng, W.; Cao, D.; Luo, X. Can mixed reality enhance safety communication on construction sites? An industry perspective. Saf. Sci. 2021, 133, 105009. [CrossRef]

31. Derahim, N.; Arifin, K.; Isa, W.W.; Khairil, M.; Mahfudz, M.; Ciyo, M.; Ali, M.; Lampe, I.; Samad, M. Organizational Safety Climate Factor Model in the Urban Rail Transport Industry through CFA Analysis. Sustainability 2021, 13, 2939. [CrossRef]

32. Lestari, F.; Sunindijo, R.Y.; Loosemore, M.; Kusminanti, Y.; Widanarko, B. A Safety Climate Framework for Improving Health and Safety in the Indonesian Construction Industry. Int. J. Environ. Res. Public Health 2020, 17, 7462. [CrossRef] [PubMed]

33. Mosly, I.; Makki, A.A. Safety Climate Perceptions in the Construction Industry of Saudi Arabia: The Current Situation. Int. J. Environ. Res. Public Health 2020, 17, 6717. [CrossRef] [PubMed]

34. Suki, N.M.; Rony, N.I.; Suki, N.M. Do gender and income really moderate on employees' job satisfaction? Insights from Malaysia's oil and gas industry. Int. J. Manag. Sci. Eng. Manag. 2019, 15, 47-58. [CrossRef]

35. Taguiri, R. The concepts of organizational climate. In Organizational Climate: Exploration of a Concept; Tagiuri, R., Litwin, G.H., Eds.; Harvard University Press: Boston, MA, USA, 1968.

36. Lee, Y.; Kim, J. Cultivating employee creativity through strategic internal communication: The role of leadership, symmetry, and feedback seeking behaviors. Public Relat. Rev. 2021, 47, 101998. [CrossRef]

37. Little, K.E.; Martinez, K.M.; Forman, J.L.; Richter, J.P.; Wade, M.L. Improving Readiness and Reducing Costs. J. Health Manag. 2017, 62, 260-270. [CrossRef]

38. Dahl, Ø.; Kongsvik, T. Safety climate and mindful safety practices in the oil and gas industry. J. Saf. Res. 2018, 64, 29-36. [CrossRef] [PubMed]

39. Mhaskar, A.A. Differences in Interpersonal Skills between Engineering and Organizational Leadership and Supervision Majors. Master's Thesis, Purdue University, Lafayette, IN, USA, 23 July 2010.

40. Newnam, S.; Goode, N. Communication in the workplace: Defining the conversations of supervisors. J. Saf. Res. 2019, 70, 19-23. [CrossRef] [PubMed]

41. Luo, Y.; Shenkar, O. The multinational corporation as a multilingual community: Language and organization in a global context. J. Int. Bus. Stud. 2006, 37, 321-339. [CrossRef]

42. Ooi, K.-B.; Cheah, W.-C.; Lin, B.; Teh, P.-L. TQM practices and knowledge sharing: An empirical study of Malaysia's manufacturing organizations. Asia Pac. J. Manag. 2010, 29, 59-78. [CrossRef]

43. Reitter, D.; Moore, J.D. Alignment and task success in spoken dialogue. J. Mem. Lang. 2014, 76, 29-46. [CrossRef]

44. Tarone, E. Communication Strategies, Foreigner Talk, and Repair in Interlanguage1. Lang. Learn. 1980, 30, 417-428. [CrossRef]

45. Morsing, M.; Schultz, M.; Nielsen, K.U. The 'Catch 22' of communicating CSR: Findings from a Danish study. J. Mark. Commun. 2008, 14, 97-111. [CrossRef]

46. Nelson, C.W.; Tagiuri, R.; Litwin, G.H. Organizational Climate: Explorations of a Concept. Am. Sociol. Rev. 1970, $35,166$. [CrossRef]

47. Cooper, M.; Phillips, R. Exploratory analysis of the safety climate and safety behavior relationship. J. Saf. Res. 2004, 35, 497-512 [CrossRef] [PubMed]

48. Haslinda, A.; Saharudin, S.; Roslan, N.H.; Mohamed, R. Safety Training, Company Policy and Communication for Effective Accident Management. Int. J. Acad. Res. Bus. Soc. Sci. 2016, 6, 6. [CrossRef]

49. Vinodkumar, M.; Bhasi, M. Safety management practices and safety behaviour: Assessing the mediating role of safety knowledge and motivation. Accid. Anal. Prev. 2010, 42, 2082-2093. [CrossRef]

50. Michael, J.H.; Guo, Z.G.; Wiedenbeck, J.K.; Ray, C.D. Production supervisor impacts on subordinates' safety outcomes: An investigation of leader-member exchange and safety communication. J. Saf. Res. 2006, 37, 469-477. [CrossRef]

51. Sordani, Y. The Relationship Between Safety Climate and Safety Commitment: A Case Study in Alps Electric (Malaysia) Sdn Bhd Master's Thesis, Universiti Utara Malaysia, Sintok, Malaysia, 2011.

52. Faul, F.; Erdfelder, E.; Buchner, A.; Lang, A.-G. Statistical power analyses using G*Power 3.1: Tests for correlation and regression analyses. Behav. Res. Methods 2009, 41, 1149-1160. [CrossRef]

53. Hair, J.F.; Sarstedt, M.; Ringle, C.M.; Mena, J.A. An assessment of the use of partial least squares structural equation modeling in marketing research. J. Acad. Mark. Sci. 2012, 40, 414-433. [CrossRef]

54. Henseler, J.; Hubona, G.; Ray, P.A. Using PLS path modeling in new technology research: Updated guidelines. Ind. Manag. Data Syst. 2016, 116, 2-20. [CrossRef]

55. Sarstedt, M.; Ringle, C.M.; Hair, J.F. Partial Least Squares Structural Equation Modeling. In Handbook of Market Research; Springer International Publishing: Cham, Switzerland, 2017; pp. 1-40. ISBN 978-1-4522-1744-4.

56. Ramayah, T.; Cheah, J.; Chuah, F.; Ting, H.; Memon, M.A. Partial Least Squares Structural Equation Modeling (PLS-SEM) Using SmartPLS 3.0: An Update and Preactical Guide to Statistical Analysis; Pearson: Kuala Lumpur, Malaysia, 2018; ISBN $0003-2999$.

57. Henseler, J.; Ringle, C.M.; Sarstedt, M. A new criterion for assessing discriminant validity in variance-based structural equation modeling. J. Acad. Mark. Sci. 2015, 43, 115-135. [CrossRef] 
58. Hair, J.F.; Risher, J.J.; Sarstedt, M.; Ringle, C.M. When to use and how to report the results of PLS-SEM. Eur. Bus. Rev. 2019, 31, 2-24. [CrossRef]

59. Preacher, K.J.; Hayes, A.F. Asymptotic and resampling strategies for assessing and comparing indirect effects in multiple mediator models. Behav. Res. Methods 2008, 40, 879-891. [CrossRef] [PubMed]

60. Lantara, A.N.F. The effect of the organizational communication climate and work enthusiasm on employee performance. Manag. Sci. Lett. 2019, 9, 1243-1256. [CrossRef]

61. Neill, M.S.; Men, L.R.; Yue, C.A. How communication climate and organizational identification impact change. Corp. Commun. Int. J. 2019, 25, 281-298. [CrossRef]

62. Wold, T.; Laumann, K. Safety Management Systems as communication in an oil and gas producing company. Saf. Sci. 2015, 72, 23-30. [CrossRef]

63. Ishak, I.C.; Azlan, M.F.; Ismail, S.B.; Zainee, N.M.; Lumpur, M.U.K. A study of human error factors on maritime accident rates in maritime industry. Asian Acad. Manag. J. 2019, 24, 17-32. [CrossRef]

64. Davidson, D.J.; Rollins, C.; Lefsrud, L.; Anders, S.; Hamann, A. Just don't call it climate change: Climate-skeptic farmer adoption of climate-mitigative practices. Environ. Res. Lett. 2018, 14, 034015. [CrossRef]

65. Ahmad, M.A.; Ismail, N.; Othman, M.R. Dust Explosion Incidents in Malaysia for Powder Manufacturing Industries. Int. J. Acad. Res. Bus. Soc. Sci. 2017, 7, 2222-6990. [CrossRef]

66. Wiengarten, F.; Longoni, A. How does uncertainty affect workplace accidents? Exploring the role of information sharing in manufacturing networks. Int. J. Oper. Prod. Manag. 2018, 38, 295-310. [CrossRef]

67. Nwagbara, U.; Brown, C. Communication and Conflict Management: Towards the Rhetoric of Integrative Commu-nication for Sustainability in Nigeria's Oil and Gas Industry. Econ. Insights Trends Chall. 2014, 66, 15-23.

68. Wagenknecht, T.; Teubner, T.; Weinhardt, C. A Janus-faced matter-The role of user anonymity for communication persuasiveness in online discussions. Inf. Manag. 2018, 55, 1024-1037. [CrossRef]

69. Morrow, P.C. Managing organizational commitment: Insights from longitudinal research. J. Vocat. Behav. 2011, 79, 18-35. [CrossRef] 